\title{
$\begin{array}{ll}\text { Research Square } & \text { Preprints are preliminary reports that have not undergone peer review. } \\ \text { They should not be considered conclusive, used to inform clinical practice, }\end{array}$

\section{A Systematic Review on Adolescents' Premarital Sexual Behaviour In Malaysia}

Halimatus Sakdiah Minhat ( $\sim$ halimatus@upm.edu.my )

University Putra Malaysia

Raja Nurul Najwa Raja Ismail

Universiti Putra Malaysia

Faridah Jafri

Universiti Putra Malaysia

Nor Afiah Mohd Zulkefli

Universiti Putra Malaysia

Norliza Ahmad

Universiti Putra Malaysia

\section{Research article}

Keywords: Adolescents, Sexual behaviours, Premarital, Malaysia

Posted Date: February 10th, 2021

DOI: https://doi.org/10.21203/rs.3.rs-200469/v1

License: (c) (i) This work is licensed under a Creative Commons Attribution 4.0 International License. Read Full License 


\section{Abstract}

Background: Premarital sexual behaviours among adolescents and the associated negative consequences of teenage pregnancy is an increasing public health concerns in Malaysia. Despite the extensive research related to sexual and reproductive health of adolescents, the problems remain reflecting the possible poor understanding of the underlying causes contribute to the problem. This systematic review is aimed at critically evaluating the available evidence on the contributing factors related to premarital sexual behaviours among adolescents in Malaysia.

Methods: Five databases; Scopus, MEDLINE/ PubMed, CINAHL, Science Direct and Google Scholar were utilized to systematically searched related articles up to July 2018. Searching involved local quantitative, qualitative and mixed methods studies with premarital sexual behaviours among adolescents in Malaysia being the primary outcome. Two reviewers independently extracted data and assessed study risks of bias.

Results: We identified 1762 articles, of which only nine articles were included, which was dominated by six cross sectional studies. A total of 41939 adolescents aged between 12 to 19 years old were included in this review. The prevalence of premarital sexual behaviours among adolescents was ranging between $2.9 \%$ to $8.3 \%$, reported by history of ever had sex. Religiosity, attitude towards sexual urge (pornography and masturbation), high-risk behaviours (bullying, smoking and substance intake - alcohol and drugs) and parents-peers influence were main contributing factors identified to associate with premarital sexual behaviours.

Conclusion: Negative attitude towards sexual urge and involvement in high risk behaviours put adolescents at higher risk of premarital sexual behaviour, while religious beliefs and reciprocal relationship between parents and peers influence may act as protective factors. However, more qualitative, and mixed methods studies needed to get in-depth understanding on the relationship between these factors and premarital sexual behaviours.

\section{Background}

Adolescence is the phase of life between childhood and adulthood, from ages 10 to 19, characterised by rapid physical, cognitive and psychosocial growth, indicating an important time for laying the foundations of good health [1]. They make up about $20 \%$ of the world's population [2] and is considered vulnerable population to engaging in poor and risky sexual behaviours, such as unprotected sexual intercourse and having multiple partners, which can result in adverse health outcomes, including unintended pregnancy and HIV or other sexually transmitted diseases [3]. Sexual activity among adolescents varies markedly by gender and region with more girls reported sexually active in sub-Saharan Africa, Asia, and central Asia compared to in Latin America and Caribbean, which were dominated by boys [4].

The unsafe and risky sexual practices put them at risk of complicated pregnancies and childbirth, which are listed as one of the leading causes of death among adolescent girls aged 15 to 19 years [5]. Teenage pregnancy has been linked with poor outcomes particularly related to multiple maternal and children's health risks. A report by WHO in 2011 demonstrated that 15.9 million infants were born to adolescent mothers among whom at higher risk of dying at their first two years of life, with approximately $15 \%$ of total number of maternal mortality were among young women worldwide [6].

In Malaysia, the prevalence of adolescents who ever had sex had increased steadily throughout the years with reducing age pattern observed. In 2017, $7.3 \%$ of secondary school aged adolescents aged 13 to 17 years old 
reported to have experienced a sexual event, compared to only $1 \%$ in 1995 [7]. Significant numbers of quantitative studies have been published locally related to risky sexual behaviours among adolescents and its negative sequelae with very limited qualitative or mixed methods studies exploring the same problem. Despite the intensified efforts to educate the community as a whole and adolescents particularly, the public health concern related to Malaysian adolescents' sexual behaviours remained. By reviewing quantitative and qualitative studies, this article aims to identify the contributing factors of premarital sexual behaviours among the Malaysian adolescents.

\section{Methods}

This review was conducted and reported in accordance with the Preferred Reporting Items for Systematic Reviews and Meta-Analyses (PRISMA) guidelines [37].

\section{Eligibility criteria}

We included observational, qualitative, and mixed methods studies that identified, predict, explored and explained factors associated with premarital sexual behaviours among adolescents in Malaysia. We excluded experimental studies, non-English language studies, editorial, proceedings, descriptive studies, protocol, and studies among nonMalaysians living in Malaysia and articles published before the year of 2008.

\section{Data sources and search strategy}

We systematically searched for relevant articles published in Scopus, MEDLINE/ PubMed, CINAHL, Science Direct and Google Scholar up to July 2018. The search was limited to 10 years, from 2008 until 2018. Combination of keywords were used: Malaysia AND adolescent OR youth OR teen* OR teenager* AND "premarital sex" OR "premarital sexual activity" OR "premarital sexual intercourse" OR "sex before marriage" AND behaviour OR behaviour in the abstract, title or keywords fields.

\section{Study selection}

A pair of authors independently assessed the titles and abstracts of a defined set of articles based on the keywords used. Each study was recorded as include, exclude or unclear. The full articles were retrieved to further assess the include and unclear categorized articles. Eligible studies were identified based on the pre-determined inclusion criteria. Discussion between authors were conducted to identify discrepancies in the assessment in order to achieve consensus on the final articles should be included in the review.

\section{Data extraction, data analysis and quality assessment}

The data from the selected studies were extracted according to prevalence of adolescents' premarital sexual activities, and the contributing factors associated with premarital sexual behaviours. Data extraction from all potential studies was documented in Table 1 (See Table 1). The table included information related to the study design, study characteristics (year of study, study objective and sample size), characteristics of study population (age and setting) and the key findings of individual articles. 
Table 1

Description of studies included for the review and their key findings.

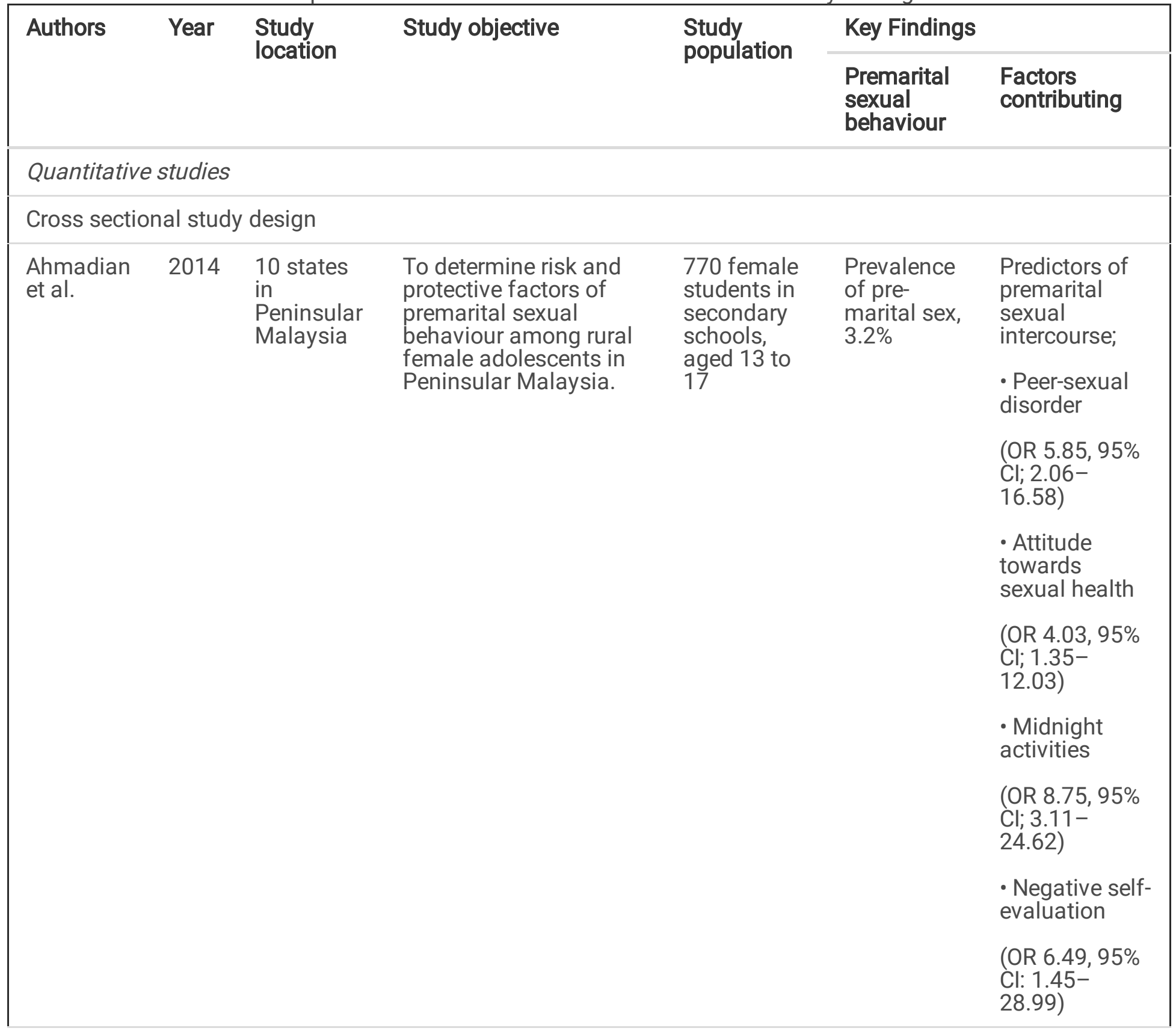




\begin{tabular}{|c|c|c|c|c|c|c|}
\hline \multirow[t]{2}{*}{ Authors } & \multirow[t]{2}{*}{ Year } & \multirow{2}{*}{$\begin{array}{l}\text { Study } \\
\text { location }\end{array}$} & \multirow[t]{2}{*}{ Study objective } & \multirow{2}{*}{$\begin{array}{l}\text { Study } \\
\text { population }\end{array}$} & \multicolumn{2}{|l|}{ Key Findings } \\
\hline & & & & & $\begin{array}{l}\text { Premarital } \\
\text { sexual } \\
\text { behaviour }\end{array}$ & $\begin{array}{l}\text { Factors } \\
\text { contributing }\end{array}$ \\
\hline \multirow[t]{10}{*}{$\begin{array}{l}\text { Abdul } \\
\text { Manaf et } \\
\text { al. }\end{array}$} & \multirow[t]{10}{*}{2014} & \multirow[t]{10}{*}{ Selangor } & \multirow[t]{10}{*}{$\begin{array}{l}\text { To identify prevalence } \\
\text { of premarital sex } \\
\text { among youth } \\
\text { undergoing national } \\
\text { skill training program } \\
\text { and to evaluate the } \\
\text { predictors. }\end{array}$} & \multirow[t]{10}{*}{$\begin{array}{l}1328 \text { youth } \\
\text { trainee in } \\
\text { PLKN } \\
\text { institutions } \\
\text { aged } 18\end{array}$} & \multirow[t]{10}{*}{$\begin{array}{l}\text { Prevalence } \\
\text { of pre- } \\
\text { marital sex, } \\
4.6 \%\end{array}$} & $\begin{array}{l}\text { Significant } \\
\text { predictors; } \\
\text { - Other races } \\
\text { (AOR 2.8, 95\% } \\
\text { Cl; 1.1-7.1) }\end{array}$ \\
\hline & & & & & & - Religion \\
\hline & & & & & & $\begin{array}{l}\text { (AOR 11.7, } \\
95 \% \text { Cl; } 1.3- \\
\text { 107.1) }\end{array}$ \\
\hline & & & & & & - Have lover \\
\hline & & & & & & $\begin{array}{l}\text { (AOR 5.1, } \\
95 \% \mathrm{Cl} ; 2.6- \\
9.8)\end{array}$ \\
\hline & & & & & & $\begin{array}{l}\text { - Have read or } \\
\text { watched } \\
\text { pornography } \\
\text { (AOR 4.1,95\% } \\
\text { Cl; } 1.8-9.3 \text { ) }\end{array}$ \\
\hline & & & & & & - Masturbate \\
\hline & & & & & & $\begin{array}{l}\text { (AOR 2.7, 95\% } \\
\mathrm{Cl} ; 1.3-5.6)\end{array}$ \\
\hline & & & & & & • Bully \\
\hline & & & & & & $\begin{array}{l}\text { (AOR 6.1,95\% } \\
\text { Cl; 1.8-20.6) }\end{array}$ \\
\hline \multirow[t]{7}{*}{$\begin{array}{l}\text { Ahmad et } \\
\text { al. }\end{array}$} & \multirow[t]{7}{*}{2014} & \multirow[t]{7}{*}{ Malaysia } & \multirow{7}{*}{$\begin{array}{l}\text { To determine the } \\
\text { national prevalence of } \\
\text { sexual activity among } \\
\text { secondary school } \\
\text { adolescents and to } \\
\text { examine selected risk } \\
\text { and protective factors } \\
\text { associated with sexual } \\
\text { activity. }\end{array}$} & \multirow{7}{*}{$\begin{array}{l}23645 \\
\text { secondary } \\
\text { school } \\
\text { students, } \\
\text { aged } 12 \text { to } \\
17\end{array}$} & \multirow[t]{7}{*}{$\begin{array}{l}\text { Prevalence } \\
\text { of ever-had } \\
\text { sex, } 8.3 \% \text {. }\end{array}$} & $\begin{array}{l}\text { Predictors for } \\
\text { ever-had sex } \\
\text { includes; }\end{array}$ \\
\hline & & & & & & $\begin{array}{l}\text { - Ever-used } \\
\text { drugs }\end{array}$ \\
\hline & & & & & & $\begin{array}{l}\text { (AOR 7.71, } \\
95 \% \mathrm{Cl} ; 6.51- \\
9.13)\end{array}$ \\
\hline & & & & & & - Ever smoked \\
\hline & & & & & & $\begin{array}{l}\text { (AOR 1.83, } \\
95 \% \text { Cl; } 1.62- \\
2.07)\end{array}$ \\
\hline & & & & & & $\begin{array}{l}\text { - Ever- } \\
\text { consumed } \\
\text { alcohol }\end{array}$ \\
\hline & & & & & & $\begin{array}{l}\text { (AOR 1.33, } \\
95 \% \mathrm{Cl} ; 1.15-\end{array}$ \\
\hline
\end{tabular}




\begin{tabular}{|c|c|c|c|c|c|c|}
\hline \multirow[t]{2}{*}{ Authors } & \multirow[t]{2}{*}{ Year } & \multirow{2}{*}{$\begin{array}{l}\text { Study } \\
\text { location }\end{array}$} & \multirow[t]{2}{*}{ Study objective } & \multirow{2}{*}{$\begin{array}{l}\text { Study } \\
\text { population }\end{array}$} & \multicolumn{2}{|c|}{ Key Findings } \\
\hline & & & & & $\begin{array}{l}\text { Premarital } \\
\text { sexual } \\
\text { behaviour }\end{array}$ & $\begin{array}{l}\text { Factors } \\
\text { contributing }\end{array}$ \\
\hline & & & & & & 2.53) \\
\hline & & & & & & •Indians \\
\hline & & & & & & $\begin{array}{l}\text { (AOR 1.32, } \\
95 \% \mathrm{Cl} ; 1.01- \\
1.65)\end{array}$ \\
\hline & & & & & & $\begin{array}{l}\text { Protective } \\
\text { factors } \\
\text { include; }\end{array}$ \\
\hline & & & & & & $\begin{array}{l}\text { - Parental } \\
\text { connectedness }\end{array}$ \\
\hline & & & & & & $\begin{array}{l}\text { (AOR 0.88, } \\
95 \% \text { Cl; 0.78- } \\
0.99 \text { ) }\end{array}$ \\
\hline & & & & & & $\begin{array}{l}\text { - Supportive } \\
\text { peers }\end{array}$ \\
\hline & & & & & & $\begin{array}{l}\text { (AOR 0.77, } \\
95 \% \mathrm{Cl} ; 0.69- \\
0.86)\end{array}$ \\
\hline & & & & & & $\begin{array}{l}\text { - Parental } \\
\text { bonding }\end{array}$ \\
\hline & & & & & & $\begin{array}{l}\text { (AOR 0.72, } \\
95 \% \mathrm{Cl} ; 0.65- \\
0.81 \text { ) }\end{array}$ \\
\hline & & & & & & $\begin{array}{l}\text { - Having a } \\
\text { close friend }\end{array}$ \\
\hline & & & & & & $\begin{array}{l}\text { (AOR 0.63, } \\
95 \% \text { Cl; } 0.50- \\
0.81)\end{array}$ \\
\hline
\end{tabular}




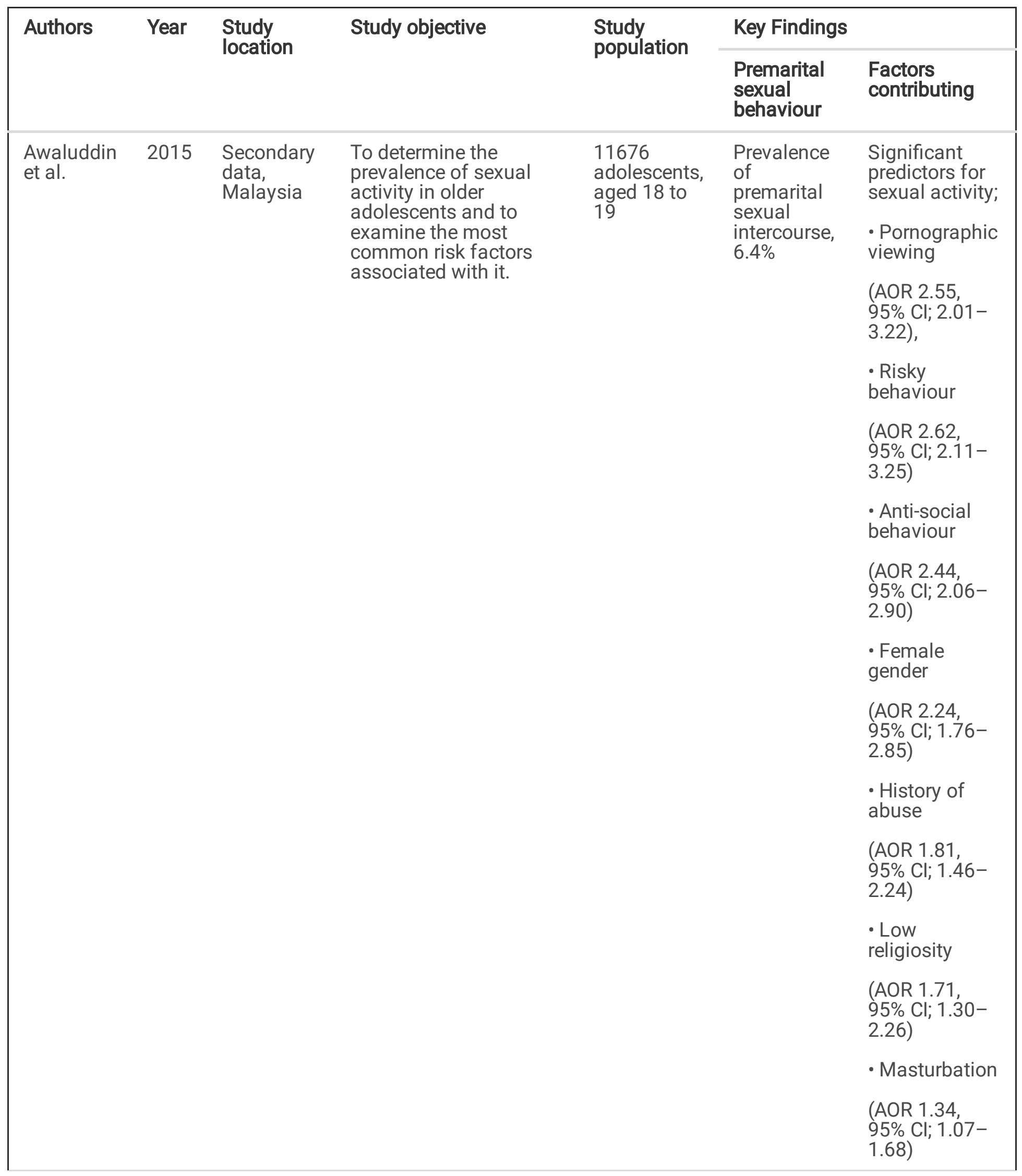




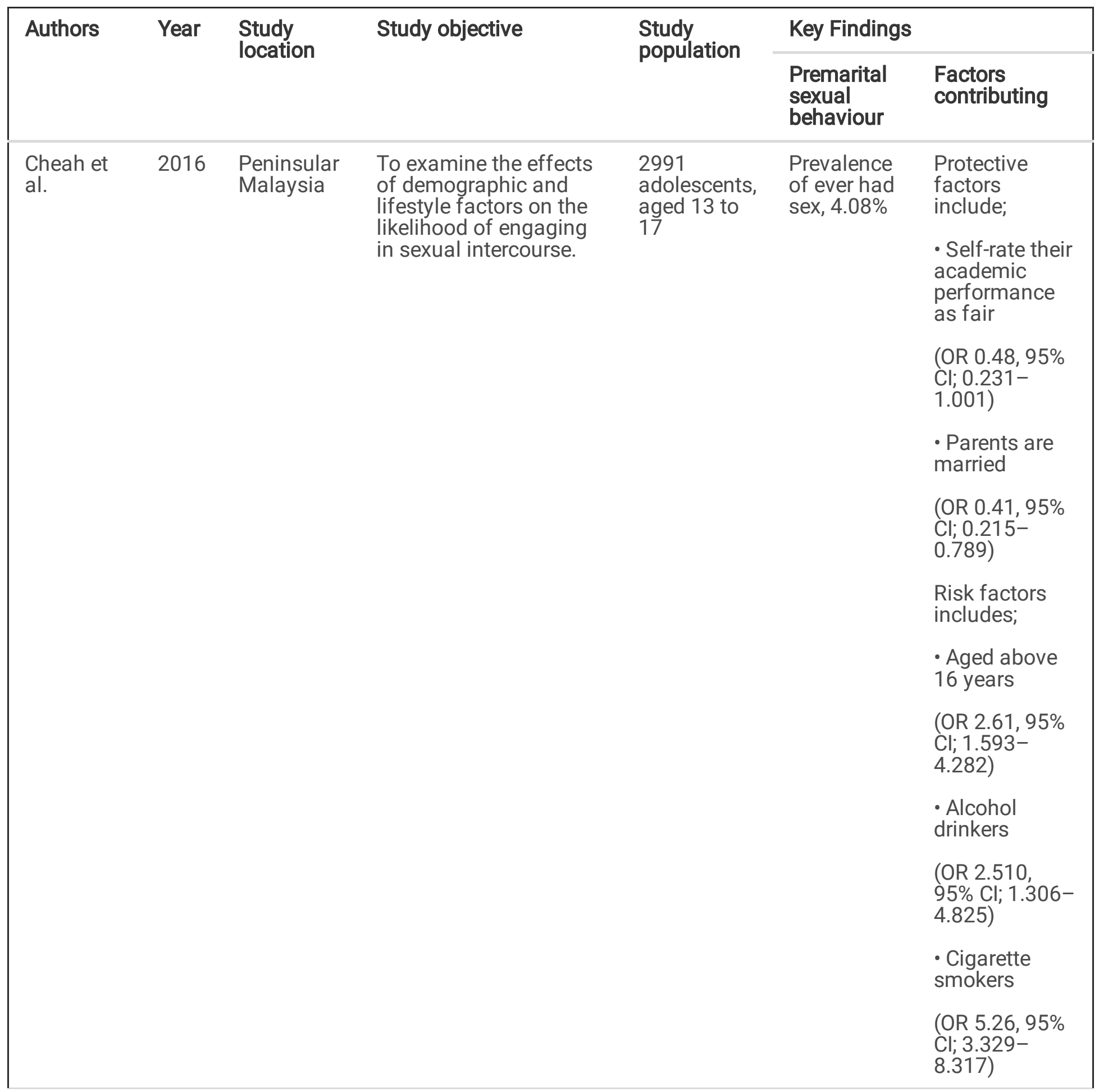




\begin{tabular}{|c|c|c|c|c|c|c|}
\hline \multirow[t]{2}{*}{ Authors } & \multirow[t]{2}{*}{ Year } & \multirow{2}{*}{$\begin{array}{l}\text { Study } \\
\text { location }\end{array}$} & \multirow[t]{2}{*}{ Study objective } & \multirow{2}{*}{$\begin{array}{l}\text { Study } \\
\text { population }\end{array}$} & \multicolumn{2}{|l|}{ Key Findings } \\
\hline & & & & & $\begin{array}{l}\text { Premarital } \\
\text { sexual } \\
\text { behaviour }\end{array}$ & $\begin{array}{l}\text { Factors } \\
\text { contributing }\end{array}$ \\
\hline Nawi et al. & 2017 & Selangor & $\begin{array}{l}\text { To determine the } \\
\text { prevalence of sexual } \\
\text { practices among } \\
\text { school-going } \\
\text { adolescents and to } \\
\text { identify predicting } \\
\text { factors associated with } \\
\text { these practices. }\end{array}$ & $\begin{array}{l}306 \\
\text { secondary } \\
\text { school } \\
\text { students, } \\
\text { aged } 16\end{array}$ & $\begin{array}{l}\text { Prevalence } \\
\text { of pre- } \\
\text { marital sex, } \\
2.9 \% \text {. }\end{array}$ & $\begin{array}{l}\text { Predictive } \\
\text { factors } \\
\text { associated } \\
\text { with } \\
\text { sexual } \\
\text { practices; } \\
\text { - Male } \\
\text { (AOR 2.7, 95\% } \\
\text { Cl; 1.4-2.5) } \\
\text { - Truancy } \\
\text { (AOR 2.3, 95\% } \\
\text { Cl; 1.3-4.2) } \\
\text { - Bully } \\
\text { (AOR 3.5, 95\% } \\
\text { Cl; 1.7-7.3) } \\
\text { • Hanging out } \\
\text { (AOR 2.8, 95\%; } \\
1.4-5.6) \\
\text { • Staying out } \\
\text { late } \\
\text { (AOR 3.2, 95\% } \\
\text { Cl; 1.5-6.8) } \\
\text { • Conflict with } \\
\text { family } \\
\text { (AOR 4.1, 95\% } \\
\text { Cl; 1.9-8.9) }\end{array}$ \\
\hline
\end{tabular}




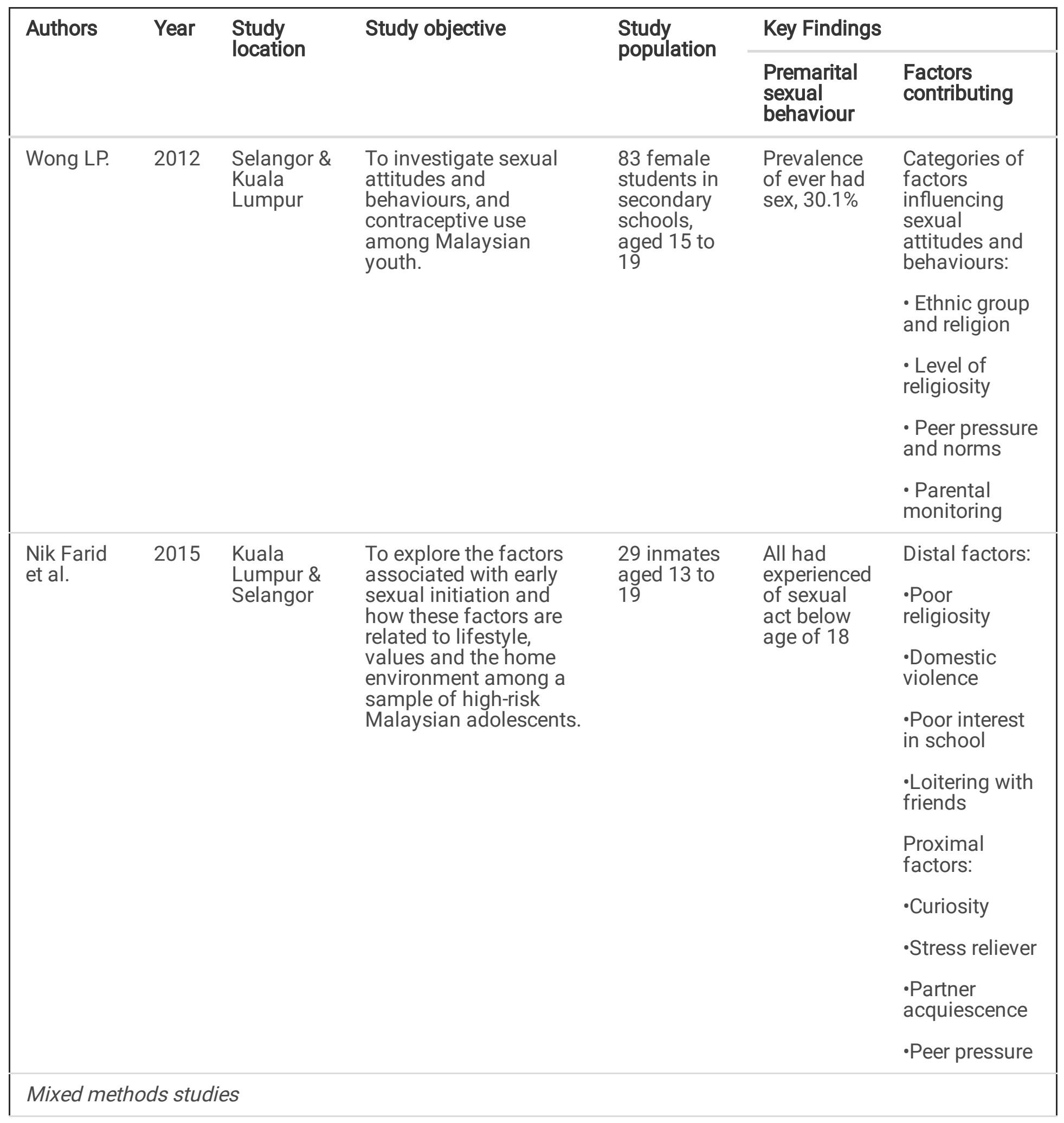




\begin{tabular}{|c|c|c|c|c|c|c|}
\hline \multirow[t]{2}{*}{ Authors } & \multirow[t]{2}{*}{ Year } & \multirow{2}{*}{$\begin{array}{l}\text { Study } \\
\text { location }\end{array}$} & \multirow[t]{2}{*}{ Study objective } & \multirow{2}{*}{$\begin{array}{l}\text { Study } \\
\text { population }\end{array}$} & \multicolumn{2}{|c|}{ Key Findings } \\
\hline & & & & & $\begin{array}{l}\text { Premarital } \\
\text { sexual } \\
\text { behaviour }\end{array}$ & $\begin{array}{l}\text { Factors } \\
\text { contributing }\end{array}$ \\
\hline \multirow[t]{16}{*}{$\begin{array}{l}\text { Nik Farid } \\
\text { et al. }\end{array}$} & 2013 & $\begin{array}{l}\text { Welfare \& } \\
\text { Rehab } \\
\text { institutions } \\
\text { in } \\
\text { Peninsular } \\
\text { Malaysia }\end{array}$ & $\begin{array}{l}\text { To investigate the } \\
\text { determinants of sexual } \\
\text { intercourse initiation } \\
\text { among incarcerated } \\
\text { adolescents aged 12- } \\
19 \text { years in Malaysia. }\end{array}$ & $\begin{array}{l}1082 \\
\text { inmates } \\
\text { aged } 12 \text { to } \\
19 \text { for } \\
\text { quantitative } \\
\text { component. }\end{array}$ & $\begin{array}{l}\text { Prevalence } \\
\text { of ever had } \\
\text { sex, } 62.3 \%\end{array}$ & $\begin{array}{l}\text { Factors } \\
\text { significantly } \\
\text { associated } \\
\text { with having } \\
\text { experienced } \\
\text { sexual } \\
\text { intercourse: }\end{array}$ \\
\hline & & & & $\begin{array}{l}29 \text { inmates } \\
\text { aged } 14 \text { to } \\
19 \text { for }\end{array}$ & & $\begin{array}{l}\cdot \text { History of } \\
\text { sexual abuse }\end{array}$ \\
\hline & & & & component. & & $\begin{array}{l}\text { (OR 5.41; } 95 \% \\
\mathrm{Cl} ; 3.52-8.32 \text { ) }\end{array}$ \\
\hline & & & & & & $\begin{array}{l}\text { - Attitudes } \\
\text { toward } \\
\text { premarital sex }\end{array}$ \\
\hline & & & & & & $\begin{array}{l}\text { (OR 4.34; 95\% } \\
\mathrm{Cl} ; 2.17-8.70)\end{array}$ \\
\hline & & & & & & $\begin{array}{l}\text { - Viewing of } \\
\text { pornography }\end{array}$ \\
\hline & & & & & & $\begin{array}{l}\text { (OR 2.84; } 95 \% \\
\mathrm{Cl} ; 1.65-4.89)\end{array}$ \\
\hline & & & & & & $\begin{array}{l}\text { - Previous } \\
\text { alcohol } \\
\text { consumption }\end{array}$ \\
\hline & & & & & & $\begin{array}{l}\text { (OR 1.80; 95\% } \\
\mathrm{Cl} ; 1.10-2.94)\end{array}$ \\
\hline & & & & & & - Illicit drug \\
\hline & & & & & & $\begin{array}{l}\text { (OR 1.85; 95\% } \\
\mathrm{Cl} ; 1.07-3.22)\end{array}$ \\
\hline & & & & & & $\begin{array}{l}\text { Themes for } \\
\text { initiation of } \\
\text { sexual } \\
\text { intercourse; }\end{array}$ \\
\hline & & & & & & $\begin{array}{l}\text { - Partner } \\
\text { influence }\end{array}$ \\
\hline & & & & & & $\begin{array}{l}\text { - Inability to } \\
\text { control sex } \\
\text { drive }\end{array}$ \\
\hline & & & & & & - Family issues \\
\hline & & & & & & $\begin{array}{l}\text { - Perception of } \\
\text { sex as an } \\
\text { expression of } \\
\text { love }\end{array}$ \\
\hline
\end{tabular}


The Crowe Critical Appraisal Tool (CCAT) was utilized in the quality assessment as the tool covered methodological assessment of both quantitative and qualitative studies [8]. The CCAT examined the studies based on eight criteria which included preliminaries, introduction, design, sampling, data collection, ethical matters, result, discussion, and conclusion. Total score was then converted into percentage whereby the following categories were assigned to allow for comparison; poor quality ( $\leq 50 \%)$, acceptable quality $(51-74 \%)$, high quality $(\geq 75 \%)[9]$.

\section{Results}

\section{Search results.}

We identified 1762 articles using the previously stated databases. After excluding 948 duplicated studies, a total of 814 articles were screened based on titles and abstracts, leading to further 765 articles excluded due to study location other than Malaysia, irrelevant topics and non-English written articles. Forty-nine full text articles were screened, of which 40 articles were further excluded for the following reasons: irrelevant outcomes (22), experimental studies (7), study population aged more than 19 years old (10) and articles with uncertain statistical analysis (1). A total of nine studies were included in this review [10-18]. Three studies were included in the qualitative analysis compared to seven studies in the quantitative analysis, with quantitative and qualitative findings of the mixed methods articles were separated accordingly for the purpose of this review. Figure 1 shows the PRISMA flowchart.

\section{Characteristics of included studies.}

A total of 41939 adolescents aged between 12 to 19 years old were included in this review. Seven studies were conducted at various states in the peninsular of Malaysia, one article was published based on the National Health Morbidity Survey 2012 data and the other article was published based on a national health screening data among adolescents conducted in 2010. A total of six studies conducted among secondary school adolescents [10,12, 14, $15,16]$ and another three were among institutionalized adolescents such as National Service Training Program (PLKN) and rehabilitation homes $[11,18]$. Among all, two studies recruited only female participants $[10,16]$.

\section{Quality assessment.}

Quality assessment for each study was conducted using Crowe Critical Analysis Tool; an established and validated tool used in assessing quality of observational studies [8]. A total of seven studies were rated as of high-quality with percentage scores ranged between 75 to $85 \%$ and the remaining two were rated as of acceptable quality (total score ranged between $51-74 \%$ ) [9] as tabulated in Table 2. 
Table 2

Crowe Critical Analysis Tool Result

\begin{tabular}{|c|c|c|c|c|c|c|c|c|c|}
\hline Category & $\begin{array}{l}\text { Wong, } \\
\text { L., P. } \\
\text { et al } \\
(2012)\end{array}$ & $\begin{array}{l}\text { Nik } \\
\text { Farid, } \\
\text { N., D., } \\
\text { et al } \\
\text { (2013) }\end{array}$ & $\begin{array}{l}\text { Ahmadian } \\
\text { et al., } \\
\text { (2014) }\end{array}$ & $\begin{array}{l}\text { Abdul } \\
\text { Manaf, } \\
\text { et al } \\
(2014)\end{array}$ & $\begin{array}{l}\text { Ahmad } \\
\text { et al } \\
(2014)\end{array}$ & $\begin{array}{l}\text { Awaludin } \\
\text { et al } \\
(2015)\end{array}$ & $\begin{array}{l}\text { Nik } \\
\text { Farid } \\
\text { et al } \\
\text { (2015) }\end{array}$ & $\begin{array}{l}\text { Cheah } \\
(2016)\end{array}$ & $\begin{array}{l}\text { Nawi } \\
\text { et al } \\
(2017)\end{array}$ \\
\hline $\begin{array}{l}\text { Preliminaries } \\
(/ 5)\end{array}$ & 5 & 5 & 5 & 4 & 4 & 4 & 5 & 5 & 5 \\
\hline $\begin{array}{l}\text { Introduction } \\
(/ 5)\end{array}$ & 4 & 4 & 4 & 3 & 5 & 5 & 4 & 4 & 4 \\
\hline Design (/5) & 4 & 5 & 5 & 3 & 5 & 4 & 3 & 4 & 5 \\
\hline $\begin{array}{l}\text { Sampling } \\
(/ 5)\end{array}$ & 5 & 4 & 4 & 3 & 4 & 3 & 4 & 3 & 4 \\
\hline $\begin{array}{l}\text { Data } \\
\text { collection } \\
(/ 5)\end{array}$ & 4 & 4 & 4 & 3 & 4 & 4 & 4 & 3 & 4 \\
\hline $\begin{array}{l}\text { Ethical } \\
\text { matters (/5) }\end{array}$ & 5 & 5 & 5 & 3 & 5 & 4 & 4 & 3 & 4 \\
\hline Results (/5) & 4 & 4 & 4 & 4 & 4 & 3 & 3 & 3 & 4 \\
\hline $\begin{array}{l}\text { Discussion } \\
(/ 5)\end{array}$ & 5 & 5 & 5 & 3 & 5 & 3 & 4 & 2 & 4 \\
\hline $\begin{array}{l}\text { Total score } \\
(/ 40)\end{array}$ & 36 & 36 & 36 & 26 & 36 & 30 & 31 & 27 & 34 \\
\hline $\begin{array}{l}\text { Percentage } \\
(\%)\end{array}$ & 90 & 90 & 90 & 65 & 90 & 75 & 77.5 & 67.5 & 85 \\
\hline
\end{tabular}

Prevalence of premarital sexual behaviours among Malaysian adolescents.

Prevalence of premarital sexual behaviours among the Malaysia adolescents as reported by history of ever had sex, ranged from $2.9-8.3 \%$ among secondary school adolescents $[10,12,14,15,16]$ and as high as $62.3 \%$ among those that were institutionalised [18]. Two studies were conducted in Selangor which recorded prevalence of $4.6 \%$ in 2014 [11] and 2.9\% in 2017 [15]. Other studies did not specifically mention their study location but were being generalized to either peninsular or east Malaysia. On average, the mean age of was 14 years old $[10,12,18]$.

\section{Contributing factors of premarital sexual behaviours among Malaysian adolescents.}

All quantitative studies included in this review used questionnaires as their study aimed to measure the association between contributing factors and adolescents' premarital sexual behaviours, presented as odds ratio (OR) or adjusted odds ratio (AOR). We have specifically categorized the factors identified in this review according to the constructs of the Social Cognitive Theory, personal, behaviour and environmental factors.

\section{a. Personal factors}

All the studies included reported mixed findings related to the role of personal factors predicting premarital sexual behaviours among adolescents. Religiosity was mentioned in two of the cross-sectional studies and both qualitative studies $[11,13,16,17]$, with low religiosity was reported to associated with higher risk of premarital 
sexual behaviours among adolescents. Abdul Manaf et al. [11] reported the highest odds of 11.7 likelihood towards sexual behavior among adolescent due to religiosity (AOR 11.7, 95\% Cl: 1.3-107.1).

b. Behaviour factors

The review found that most of the articles emphasized the role of behavioural factors predicting premarital sexual behaviours, particularly attitude and involvement in high-risk behaviours. Attitude towards sexual urge, which was also reported by the act of watching and reading pornography and masturbation significantly predict sexual behavior in three of the cross-sectional studies and also in the mixed methods study $[10,11,13,18]$. Meanwhile, high-risk behaviours such as bullying, smoking and substance intake (alcohol and drugs) were also significantly

predicted sexual behaviours among Malaysian adolescents in five of the cross-sectional studies $[11,12,13,14,15]$. History of ever used drug predicted the highest likelihood of 7.71 odds towards sexual behaviours among adolescents [12], compared to 6.1 odds by bullying [11].

\section{c. Environmental factors}

Meanwhile, family and peers related factors were identified under environmental factors that were associated with sexual behaviours among adolescents. The influence of family, particularly parental role on involvement of adolescents in sexual behaviours were reported in three of the cross-sectional studies [12, 14, 15], one qualitative study [16] and the qualitative findings of the mixed methods study [18]. Having both parents who are still married served as the strongest protective factor (OR 0.41, 95\% Cl; 0.215-0.789) among Malaysian adolescents, with 59\% less likelihood to be involved in sexual behaviours [14]. Meanwhile, the role of peers in influencing sexual behaviours among adolescents were more prominent in the qualitative findings in both qualitative studies [16, 17] and the mixed methods study [18]. Only two of the cross-sectional studies reported the role of peer in influencing sexual behaviours among Malaysian adolescents [10, 12].

\section{Discussion}

\section{Prevalence of premarital sexual behaviours among adolescent in Malaysia.}

The review found the prevalence of pre-marital sexual behaviour among Malaysian adolescents ranged between 2.9 and $8.3 \%$. The review finding was higher in comparison to finding by national health survey in 1996 which reported prevalence of ever had sex among adolescents at $1.8 \%$ but the prevalence range were in keeping with subsequent series of national surveys on adolescents' at $8.3 \%$ in 2012 [19] and 7.3\% in 2017 [7]. The poor response rate and the lack of representativeness in the selection of study population in the study by Nawi et al. [15] may have contributed to the low prevalence of premarital sexual behaviour among adolescents. Additionally, the use of self-reported and non-anonymous questionnaires among seven studies may have led to under-reporting of the prevalence of pre-marital sex among Malaysian adolescents.

Nevertheless, the reported prevalence of pre-marital sex behaviour among Malaysian adolescents in these studies were lower as compared to the neighbouring countries, including 11.2\% in Brunei [20] and 11.0\% in Thailand [21], but higher as compared to Cambodia (8\%) and Vietnam (3\%) [22]. Possible causes for the variation could be due to characteristics of the respondents, tools used to collect the data and locality of study.

Contributing factors associated with adolescents' premarital sexual behaviours.

Page $14 / 20$ 
The role of religion was the only personal factor consistently reported in few of the articles reviewed, particularly in the qualitative results. Having a more conservative religious connection reported to delay sexual debut [23]. A review done in the United States which analysed evidence of adolescents' religiosity causal relationship with their sexual behaviours noted all 10 longitudinal studies conducted from 1980 to 2000 reported that religious adolescents and those who were actively attending religious activities were unlikely to be involved in sexual activity [23], reflecting the important role of religious beliefs in shaping adolescents' sexual behaviour.

Meanwhile, attitude towards sexual urge and involvement in high-risk behaviours were important factors contributed towards sexual behaviours among Malaysian adolescents, identified from this review. Masturbation and reading or watching pornography were two manifestations of negative attitude towards sexual urge reported to predict sexual behaviours among adolescents in this review. Masturbation or solitary sex is defined as an act of exciting one's sexual organs by rubbing, stroking, pressing, folding or other forms of manipulation to reach orgasm [24]. According to Herbenick et al. [25], the physiological changes and emergence of sexual urges among adolescents may be manifested in the form of masturbation or other activities, ranging from hugging and kissing to vaginal intercourse. Association between masturbation and pornography watching has been reported in previous studies as well. In a case study of undergraduate students in Bangladesh found that, the prevalence of masturbation among the students was $33 \%$ and was significantly higher among male students [26]. The study also reported, students who watched pornography at least once a week (OR: $161.43,95 \% \mathrm{Cl}=38.64-674.39)$ or once a month (OR: $112.30,95 \% \mathrm{Cl}=22.80-553.22$ ) were more likely to masturbate. Pornography consumption was also reported to positively associated with extramarital sex.

Similarly, risky behaviours such as cigarette smoking, intake of drugs and alcohol were also found as main contributors towards adolescents' premarital sexual behaviour. These factors were also consistently reported as significant predictors of premarital sexual behaviour in several other Asian countries such as India, China, Indonesia, Thailand and Vietnam [22]. A recent local study also reported that history of ever used drugs (AOR = 10.201) and ever smoked (AOR = 1.628) were significantly associated with sexual activity of adolescents [27]. According to Hops et al. [28], adolescents who abuse substances are more likely to engage in health-risking sexual behaviour (HRSB) and are at particularly high risk for HIV/AIDS. Evidence showed that as many as $22.1 \%$ of adolescents engaged in substance use during their most recent sexual encounter [29]. Adolescents who regularly abuse substances are more likely to become sexually active at an earlier age [30], have more sexual partners [31], and are more likely to have unprotected sex [32]. A meta-analysis on risky sexual behaviour and substance use among adolescents reported the role of moderators such as sex, ethnicity and age on the relationship between drug use and risky sexual behaviour [33].

On the other hand, parents and peers were found to be important protective factors towards sexual behaviours among Malaysian adolescents. Wang et al., [3] suggested that there are reciprocal relationships between parenting, peer influence and adolescent sexual risk involvement. Parents and peers are two major potential influences on risky and protective behaviours among adolescents by creating a social context for behavioural development, act as role models, and provide opportunity and reinforcement for risk and protective behaviours [3]. Interestingly, literatures have also reported the interplay between parental and peer influences in order to better understand risky behaviours among adolescents. Parental monitoring may buffer negative peer influence on adolescent risk involvement [34], influence the type of peers with whom adolescents associate [35] and decrease the likelihood that adolescents will affiliate with deviant peer groups [36]. To effectively reduce sexual risks among adolescents, peers and parents should be included in any related intervention [3].

Page $15 / 20$ 


\section{Conclusion}

Premarital sexual involvement among Malaysian adolescents is increasing and is affecting adolescents of younger age groups. Religious beliefs, attitude towards sexual urge (masturbation and pornography watching), high-risk behaviours (smoking and substance intake), and parent-peer influences were identified as contributing factors towards adolescents' sexual behaviours. The inclusion of quantitative and qualitative findings contributes to the strength for this review in order to better understand the contributing factors of Malaysian adolescents' sexual behaviours. However, the scarcity of qualitative research included in this review may also limit the overall interpretation and must be delineated with caution. Future studies should consider more qualitative exploration and mixed methods approach with incorporation of the reciprocal role pf parents and peers in intervention studies.

\section{Abbreviations}

\begin{tabular}{|ll|}
\hline SRH & Sexual and reproductive health \\
\hline HIV & Human immunodeficiency virus \\
\hline AIDS & Acquired immunodeficiency syndrome \\
\hline PRISMA & Preferred Reporting Items for Systematic Reviews and Meta-Analyses \\
\hline CCAT & Crowe Critical Appraisal Tool \\
\hline PLKN & National Service Training Program \\
\hline OR & Odds ratio \\
\hline AOR & Adjusted odds ratio \\
\hline HRSB & Health-risking sexual behaviour \\
\hline
\end{tabular}

\section{Declarations}

\subsection{Ethics approval and consent to participate}

Not applicable

7.2 Consent for publication

Not applicable

\subsection{Availability of data and materials}

All data generated or analysed during this study are included in this published article [and its supplementary information files]

\subsection{Competing interests}

The authors declare that they have no competing interests

\subsection{Funding}


Not applicable

7.6 Authors' contributions

All Authors read and approved the manuscript

MHS initiated the idea and performed full editing of the review

NRI \& FJ performed information gathering, preparation and editing of the review and was a major contributor in writing the manuscript

NAMZ and NA conducted review and editing of the manuscript

\subsection{Acknowledgements}

We thank the staff of the Department of Community Health, Faculty of Medicine of Universiti Putra Malaysia for guidance and support throughout the writing process

7.8 Authors' information (optional)

Nil

\section{References}

1. WHO. 2020. Adolescent health. https://www.who.int/health-topics/adolescent-health\#tab=tab_1.

2. Dehne K, Riedner C. Sexually transmitted Infections among adolescents. The need for adequate health services. Department of Child and Adolescent Health and Development (CAH), WHO 2005 http://whqlibdoc.who.int/publications/2005/9241562889.pdf.

3. Wang B, Stanton B, Deveaux L, Li X, Lunn S. (2015). Dynamic Relationships Between Parental Monitoring, Peer Risk Involvement and Sexual Risk Behavior Among Bahamian Mid-Adolescents. International perspectives on sexual reproductive health, 41(2), 89-98. https://doi.org/10.1363/4108915.

4. Chandra-Mouli V, McCarraher DR, Phillips SJ, Williamson NE, Hainsworth G. Contraception for adolescents in low and middle income countries: Needs, barriers, and access. Reprod Health. 2014;11:1.

5. United Nation. (2015). The global strategy for women's, children's and adolescents' health (2016-2030). Retrieved from https://www.who.int/life-course/partners/global-strategy/globalstrategyreport2016-2030lowres.pdf.

6. WHO. (2011). Youth and health risks. https://apps.who.int/gb/ebwha/pdf_files/WHA64/A64_25-en.pdf.

7. Institute for Public Health (IPH) \& Ministry of Health, Malaysia. (2017). National Health and Morbidity Survey 2017. http://iku.moh.gov.my/images/IKU/Document/REPORT/NHMS2017/NHMS2017Infographic.pdf.

8. Crowe M, Mgmt MIT, Sheppard L, Campbell A. (2011). Comparison of the effects of using the Crowe Critical Appraisal Tool versus informal appraisal in assessing health research: a randomised trial, 444-449. https://doi.org/10.1111/j.1744-1609.2011.00237.x.

9. Corrigan FM, Broome H, Dorris L. Epilepsy \& Behavior A systematic review of psychosocial interventions for children and young people with epilepsy. Epilepsy Behav. 2016;56:99-112.

https://doi.org/10.1016/j.yebeh.2016.01.005.

Page $17 / 20$ 
10. Ahmadian M, Hamsan HH, Abdullah H, Samah AA, Noor AM. (2014). Risky Sexual Behavior among Rural Female Adolescents in Malaysia: A Limited Role of Protective Factors. Global Journal of Health Science, 6(3). https://doi.org/10.5539/gjhs.v6n3p165.

11. Manaf MR, Tahir MM, Sidi H, Midin M, Nik Jaafar NR, Das S, Malek AM. Pre-marital sex and its predicting factors among Malaysian youths. Compr Psychiatry. 2014 Jan;55Suppl 1:S82-8. doi: 10.1016/j.comppsych.2013.03.008. Epub 2013 Apr 13. PMID: 23587530.

12. Ahmad N, Awaluddin SM, Ismail H, Samad R, NikAbdRashid N. Sexual Activity Among Malaysian SchoolGoing Adolescents. Asia Pacific Journal of Public Health. 2014;26(5_suppl):44S-52S. https://doi.org/10.1177/1010539514544700.

13. Awaluddin, S. M., Ahmad, N. A., Saleh, N. M., Aris, T., Kasim, N. M., Azlin, N., ...Rashid, N. A. (2015). Prevalence of sexual activity in older Malaysian adolescents and associated factors. Journal of Public Health Aspects, 2. Retrieved from http://www.hoajonline.com/journals/pdf/2055-7205-2-1.pdf.

14. Cheah YK, Lim HK, Kee CC, Mohd Ghazali S. Demographic and lifestyle factors associated with sexual activity among adolescents in Malaysia. Vulnerable Children Youth Studies. 2016;11(4):324-31. https://doi.org/10.1080/17450128.2016.1218095.

15. Nawi AM, Roslan D, Idris IB, Hod R. Bullying and truancy: Predictors to sexual practices among school-going adolescents in Malaysia - A cross-sectional study. Med J Malaysia. 2017;72(5):298-305.

16. Wong LP. An exploration of knowledge, attitudes and behaviours of young multiethnic Muslim-majority society in Malaysia in relation to reproductive and premarital sexual practices. BMC Public Health. 2012;12:1. https://doi.org/10.1186/1471-2458-12-865.

17. Nik Farid ND, Dahlui M, Che' Rus S, Aziz NA, Al-Sadat N. Early Sexual Initiation among Malaysian Adolescents in Welfare Institutions: A Qualitative Study. Arts Social Sciences Journal. 2015;06(04):4-9. https://doi.org/10.4172/2151-6200.1000129.

18. Nik Farid ND, Che' Rus S, Dahlui M, Al-Sadat N. Determinants of sexual intercourse initiation among incarcerated adolescents: A mixed-method study. Singapore Med J. 2013;54(12):695-701. https://doi.org/10.11622/smedj.2013244.

19. Institute for Public Health (IPH). (2012). The National Health and Morbidity Survey 2012. http://iku.moh.gov.my/images/IKU/Document/REPORT/2012/NHMS2012Penang.pdf.

20. Razak LA. Global School-based Student Health Survey 2014. Bandar Seri Begawan. Brunei: Ministry of Health Brunei; 2014.

21. Peltzer K, Pengpid S. Prevalence and social correlates of sexual intercourse among school-going adolescents in Thailand. ScientificWorldJournal. 2011;11:1812-20.

22. Frank N, Saky L. 2017. UNFPA Cambodia Country Programme Review: 5th Programme Cycle, 2016-2018. https://www.unfpa.org/sites/default/files/board-documents/Cambodia_Evaluation_Report_2016_2018_.pdf.

23. Rostosky SS, Wilcox BL, Wright MLC, Randall BA. The impact of religiosity on adolescent sexual behavior: $A$ review of the evidence. J Adolesc Res. 2004;19(6):677-97. https://doi.org/10.1177/0743558403260019.

24. Kabbash IA, Ali EAA, Kabbash MI, El-Naga AA. Perception and practices of masturbation by male medical students, Tanta University, Egypt. Egyptian Journal of Community Medicine. 2017;35(1):99-109.

DOI:10.21608/EJCM.2017.2814.

25. Herbenick D, Reece M, Schick V, Sanders SA, Dodge B, Fortenberry JD. (2010). Sexual behavior in the United States: Results from a national probability sample of males and females ages 14 to 94 . The Journal of Sexual

Page 18/20 
Medicine, 7 (suppl 5), 255-65. doi:10.1111/j.1743-6109.2010.02012.x.

26. Chowdhury MdRHasanK, Mohammad Rocky Khan Chowdhury, Nasrin Sultana Nipa, Russell Kabir, Mohammad Ali Moni, Maria Kordowicz. Masturbation Experience: A Case Study of Undergraduate Students in Bangladesh. Journal of Population and Social Studies, Volume 27 Number 4, October 2019: 359-372. DOI: 10.25133/JPSSv27n4.024.

27. Noor Aliza L, Hatta M, Mohd Amierul FM, Awaluddin SM, Yoep N, Paiwai F, Hasim H, Omar M, Noraida MK, Noorani A. Risky Sexual Behaviours among School-going Adolescent in Malaysia-Findings from National Health and Morbidity Survey 2017. J Environ Sci Public Health 2019; 3 [2]: 226-235.

28. Hops H, Ozechowski TJ, Waldron HB, Davis B, Turner CW, Brody JL, Barrera M. Adolescent health-risk sexual behaviors: effects of a drug abuse intervention. AIDS Behav. 2011;15(8):1664-76. https://doi.org/10.1007/s10461-011-0019-7.

29. Eaton DK, Kann L, Kinchen S, Shanklin S, Flint KH, Hawkins J, Lim C. Youth risk behavior surveillance-United States, 2011. MMWR Surveill Summ. 2012;61(4):1-162.

30. Madkour AS, Farhat T, Halpern CT, Godeau E, Gabhainn SN. Early adolescent sexual initiation as a problem behavior: A comparative study of five nations. J Adolesc Health. 2010;47(4):389-98.

31. Connell CM, Gilreath TD, Hansen NB. A multiprocess latent class analysis of the co-occurrence of substance use and sexual risk behavior among adolescents. Journal of Studies on Alcohol Drugs. 2009;70:943-51.

32. Tucker JS, Ryan GW, Golinelli D, et al. Substance use and other risk factors for unprotected sex: Results from an event-based study of homeless youth. AIDS Behav. 2012;16(6):1699-707.

33. Ritchwood TD, Ford H, DeCoster J, Sutton M, Lochman JE. Risky Sexual Behavior and Substance Use among Adolescents: A Meta-analysis. Children youth services review. 2015;52:74-88.

https://doi.org/10.1016/j.childyouth.2015.03.005.

34. DeVore ER, Ginsburg KR. The protective effects of good parenting on adolescents. Curr Opin Pediatr. 2005;17(4):460-5.

35. Rodgers-Farmer AY. Parental monitoring and peer group association: their influence on adolescent substance use. Journal of Social Service Research. 2001;27(2):1-18.

36. Sieverding JA, et al. The influence of parental monitoring on adolescent sexual initiation. Archives of Pediatrics Adolescent Medicine. 2005;159(8):724-9.

37. Schulz KF, et al. CONSORT 2010 Statement: updated guidelines for reporting parallel group randomised trials. BMC Med. 2010; 8 (18). https://doi.org/10.1186/1741-7015-8-18.

\section{Figures}




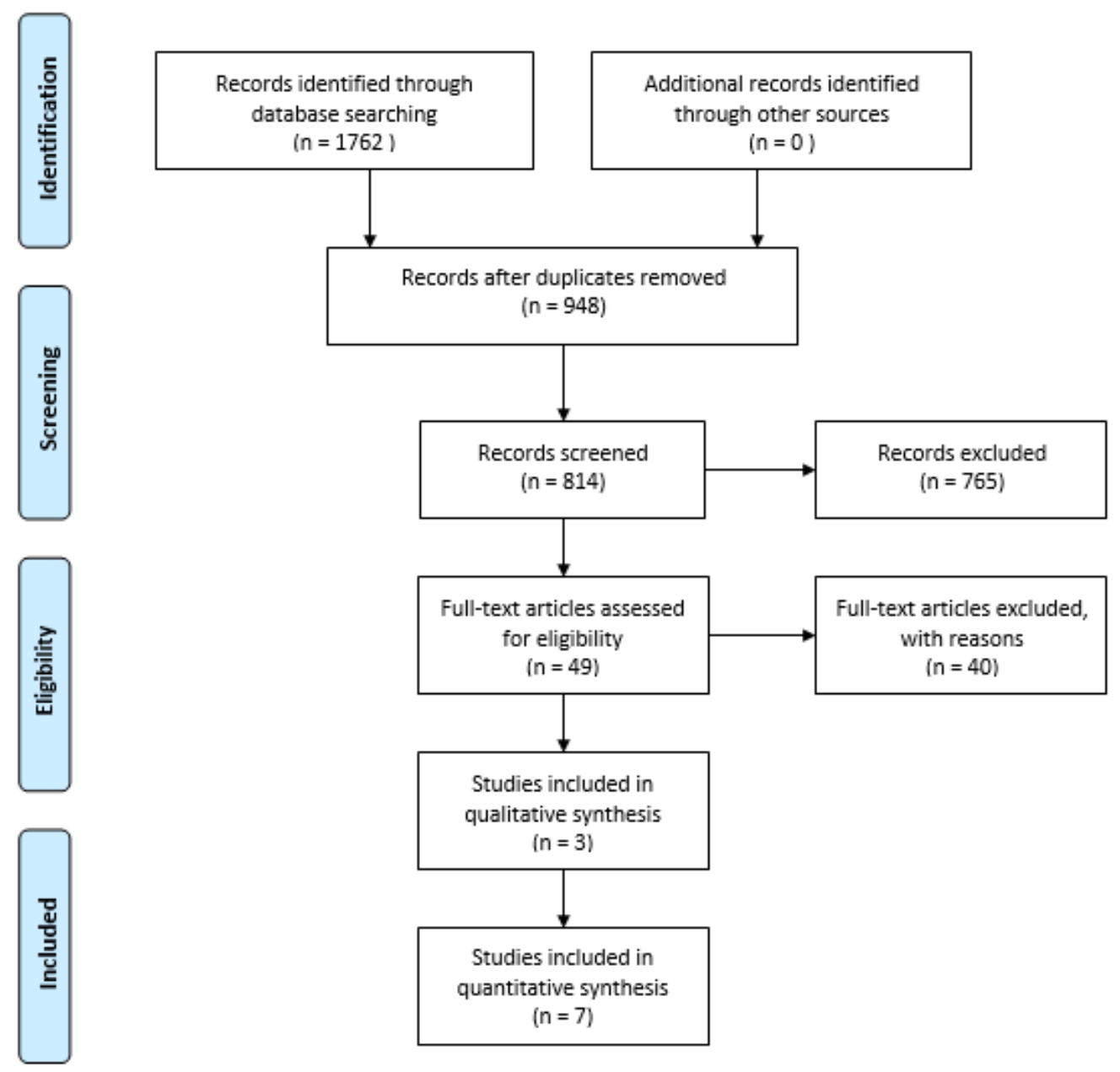

Figure 1

Flow diagram of the selection process used to identify studies for inclusion in this review based on PRISMA Statement 